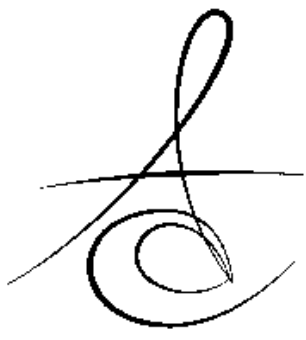

\title{
BOND STRENGTH OF SOFT LINING MATERIAL TO POLYAMIDE DENTURE MATERIAL
}

\section{YUMUŞAK ASTAR MADDESİNİN POLİAMİD KAİDE MATERYALİNE BAĞLANMA DAYANIMI}

Arş. Gör. Dt. Alper ÖZDOĞAN*

Prof. Dr. Funda BAYINDIR*

Arş. Gör. Dt. Hamza ULU*

Makale Kodu/Article code: 2654

Makale Gönderilme tarihi: 09.03 .2016

Kabul Tarihi: 30.03 .2016

\section{ABSTRACT}

Aim: The aim of this study was to evaluate the bond strength of soft lining material to polyamide denture material.

Materials and Methods: Twenty-five polyamide denture base materials and soft denture lining material were used in this study. The samples were divided into five groups according to the surface treatments:

Group 1 (Control): No surface treatment

Group 2: Samples were sandblasted with $50 \mu \mathrm{m} \mathrm{Al}_{2} \mathrm{O}_{3}$ powder.

Group 3: Samples were grinded with a diamond bur.

Group 4: Samples were etched with \% 37 Orthophosphoric acid.

Group 5: Retention holes were slotted with diamond bur to samples.

Then the samples were tested in tensile mode in a universal testing machine at cross-head speed of 0.5 $\mathrm{mm} / \mathrm{min}$. The statistically analysis of obtained data were performed with use one-way analysis of variance test.

Results: The results showed that the highest bond strength value ( $92.54 \mathrm{~N}$ ) was identified in Group 3, the lowest bond strength value (31.56 N) in Group 4. The result of one-way analysis of variance test showed that there were not statistically significant differences between the groups. ( $p>0.05$ )

Conclusion: As a result of this study, the surface treatments were not affected on bond strength of soft lining material to polyamide denture material.

Key Words: Polyamide denture, soft lining material. öz

Amaç: $\mathrm{Bu}$ çalışmanın amacı yumuşak astar maddesinin poliamid kaide maddesine bağlanma dayanımının incelenmesidir.

Gereç ve Yöntem: Çalışma kapsamında 25 adet poliamid kaide maddesi ve bir yumuşak astar maddesi kullanıldı. Örnekler yüzey işlemlerine göre beş gruba ayrıldı:

Grup 1 (Kontrol): Hiçbir yüzey işlemi uygulanmadı.

Grup 2: Örnekler $50 \mu \mathrm{m}$ partikül boyutlu $\mathrm{Al}_{2} \mathrm{O}_{3}$ tozu ile kumlandı.

Grup 3: Örnekler elmas frezle aşındırıldı.

Grup 4: Örnekler \% 37'lik ortofosforik asit ile asitlendi. Grup 5: Elmas bir frezle örneklere retansiyon olukları açıldı.

Örnekler universal test cihazında $0.5 \mathrm{~mm} / \mathrm{min}$ başlık hızı ile test edildi. Verilerin istatistiksel analizi tek yönlü varyans analizi testi ile yapıldı.

Bulgular: Sonuçlar en yüksek bağlanma dayanımı değerinin (92.54 N) 3. Grupta, en düşük bağlanma dayanımı değerinin ise (31.56 N) 4. Grupta olduğunu gösterdi. Tek yönlü varyans analizinin sonuçlarına göre gruplar arasındaki farkın istatistiksel olarak anlamlı olmadığı görüldü ( $p>0.05)$.

Sonuçlar: Yüzey işlemlerinin yumuşak astar maddesi ile poliamid kaide maddesi arasındaki bağlantı kuvvetini etkilemediği sonucuna varıldı.

Anahtar Kelimeler: Poliamid kaide maddesi, yumuşak astar maddesi.

* Atatürk Üniversitesi, Diş Hekimliği Fak. Protetik Diş Tedavisi AD 


\section{INTRODUCTION}

Polymethyl methacrylate (PMMA) resin is mostly used in removable prosthesis. PMMA resin has lots of advantageous properties: it is easy to apply and to repair, its low cost, acceptability by most of the patients, ability to be polished is good, stability in the oral cavity, and aesthetical properties. It has strength mechanical properties. These often lead to denture failure during chewing or when it is dropped..$^{1-4}$ The strength and fatigue resistance of PMMA can be effort by: 1- reinforcement of denture materials with filling materials, ${ }^{1,5,6} 2$ - changing the chemistry of PMMA resin materials and 3- manufacturing alternative denture base materials. ${ }^{5}$

Polyamide (PA) system is an alternative denture base material to PMMA. Polyamides are thermoplastic polymers produced by condensation between a diamine and a dibasic acid. ${ }^{7}$

Firstly, PA was used as a denture base polymer in the studies in 1950s and reported that because of the high water absorption and discoloration, the nylon was not suitable materials in dentistry. ${ }^{8}$ It was especially used allergic reaction and long-term denture fractures. ${ }^{9}$ In the global world, the PA has become a popular and strongly alternative system to PMMA, because it has lots of good properties such as, nonallergic, flexible, quite light, esthetic.

In dentistry, soft denture liners are used due to the viscoelastic properties. ${ }^{10-12}$ These liners act as shock absorbers in order to reduce and deploy the pressure on denture-bearing tissues, as well as to improve the intaglio denture surface. ${ }^{13-15}$ Depending on traumatic or incorrect extraction, irregular bone formation and spinous process may occur under the mucosa. The patient's age and systemic conditions may not allow the elimination of these irregularities by surgery. In this case, dentist may choose to use soft liner material under the denture base. ${ }^{16}$ The use of soft lining material will be useful the success of complete denture to reduce the occlusal stress. ${ }^{17-20}$ The major problem of soft liners is that the bonding and adhesion of denture base. ${ }^{11,15,17,21.22}$

Depending on the replacement of soft denture liners from bases, increasing patient complaints and causing mouth sores. To avoid this situation, there would be strong bonding between soft denture liner and denture bases and not replacement from the denture base. On account of this, a suitable bond between the denture base and the soft lining material is necessary. ${ }^{14,23-26}$

The aim of this study was to evaluate the bond strength of soft lining material to polyamide denture material. The hypothesis of this study was that the surface treatments will affect the bond strength of soft lining material to polyamide denture.

\section{MATERIAL AND METHODS}

The polyamide denture base material Deflex (Nuxen S.R.L.,Buenos Aires, Argentina) and Mollosil soft lining material (Detax, Karl Huber GmbH and Co., KG, Ettlingen, Germany) were used in this study. Totally twenty five rectangular prism shaped which (50X10X10 mm) were prepared. The polyamide denture base materials were injected with $720-750$ $\mathrm{kPa}$ pressure at $220{ }^{\circ} \mathrm{C}$ and pre-heating time of 15 min. After the specimens were prepared, all irregularities were removed with a tungsten carbide bur. Then, the specimens were embedded to dental stone in the stainless steel mold and moulds were created. The $2 \mathrm{~mm}$ thickness blocks were horizontally excised from the midpoint of the specimens. After that, the specimens were divided into five groups according to the surface treatments $(n=5)$ :

Group 1 (Control): No surface treatment

Group 2: The specimens were sandblasted with $50 \mu \mathrm{m}$ $\mathrm{Al}_{2} \mathrm{O}_{3}$ powder.

Group 3: The specimens were grinded with a diamond bur.

Group 4: The specimens were etched with \% 37 Orthophosphoric acid.

Group 5: The retention holes were slotted with a diamond bur to specimens. (Fig. 1)

Then, the adhesive of soft lining material (Fig. 2) was applied the all specimens' surfaces. The soft lining materials were placed in the space between two polyamide specimens. All specimens were pressed under the 3000 PSI with hydraulic presser. After the polymerization, the specimens were removed from the stainless steel molds (Fig. 3).

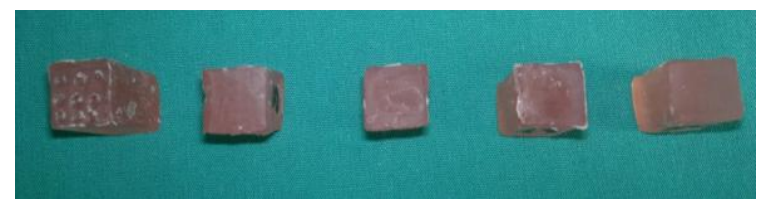

Figure 1. The surface treatments of specimens

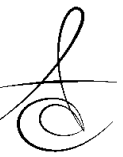


The specimens were tested in tensile mode in a universal testing machine (Instron) at cross-head speed of $0.5 \mathrm{~mm} / \mathrm{min}$. The statistically analysis of obtained data were performed with use one-way analysis of variance test.

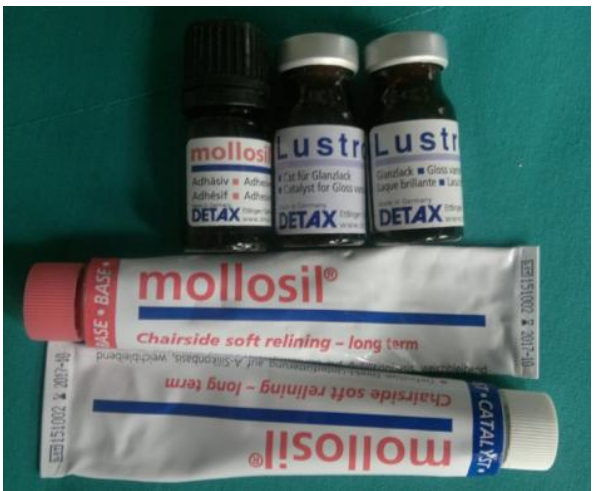

Figure 2 The soft lining material

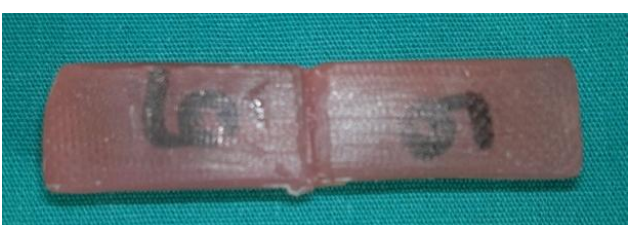

Figure 3. The soft lining materials between the specimens

\section{RESULTS}

The result of one-way analysis of variance test showed that there were not statistically significant differences between the groups of bond strength ( $p>0.05$ ) (Table 1). The results showed that the highest bond strength value (92.54 N) was identified in Group 3, the lowest bond strength value $(31.56 \mathrm{~N})$ in Group 4 (Table 2).

The diamond bur grinding, retention holes and $50 \mu \mathrm{m} \mathrm{Al}{ }_{2} \mathrm{O}_{3}$ sandblasting increased the bond strength between soft denture liners and polyamide dentures, however \% 37 Orthophosphoric acid etching decreased the bond strength soft denture liners and polyamide dentures. However, these changes were not statistically significant.

The mechanical and grinding surface treatments were more effective from sandblasting and chemical treatment was not effective.

\section{DISCUSSION}

The hypothesis set as the premise of this study was not accepted, because the surface treatments
Table 1. The one-way analysis of variance

\begin{tabular}{|c|c|c|c|c|c|}
\hline Source & $\begin{array}{l}\text { Type III Sum } \\
\text { of Squares }\end{array}$ & df & $\begin{array}{l}\text { Mean } \\
\text { Square }\end{array}$ & $\mathrm{F}$ & Sig. \\
\hline $\begin{array}{l}\text { Corrected } \\
\text { Model }\end{array}$ & 2534.653(a) & 4 & 633.663 & 1.489 & .243 \\
\hline Intercept & 100139.337 & 1 & 100139.337 & 235.363 & .000 \\
\hline Groups & 2534.653 & 4 & 633.663 & 1.489 & 243 \\
\hline Error & 8509.359 & 20 & 425.468 & & \\
\hline Total & 111183.348 & 25 & & & \\
\hline $\begin{array}{l}\text { Corrected } \\
\text { Total }\end{array}$ & 11044.012 & 24 & & & \\
\hline
\end{tabular}

Table 2. Mean bond strenght value of groups.

\begin{tabular}{|l|l|l|l|l|}
\hline Gropus & Mean & Std. rror & \multicolumn{2}{|c|}{$95 \%$ Confidence Interval } \\
\hline & & & Lower ound & JpperBound \\
\hline Group 4 & 50.79 & 9.22 & 31.55 & 70.04 \\
Group 3 & 73.29 & 9.22 & 54.05 & 92.53 \\
Group 1 & 51.52 & 9.22 & 32.28 & 70.76 \\
Group 2 & 68.09 & 9.22 & 48.85 & 87.33 \\
Group 5 & 72.74 & 9.22 & 53.49 & 91.98 \\
\hline
\end{tabular}

were not affected the bond strength of soft lining material to polyamide denture. The polyamide dentures are used as an alternative for PMMA when allergic reaction, aesthetic expectations in removable prosthesis. The polyamide dentures are lighter and have a flexible structure. Also the soft lining materials have become popular and important in dental prosthesis. There are lots of studies about the bond strength between soft lining materials and acrylic resins but not enough the bonding polyamide dentures, so this study evaluated the effect of different surface treatments on bond strength of soft lining material to polyamide dentures.

Previous studies ${ }^{25,27,28}$ have showed that Mollosil soft lining material (Detax, Karl Huber $\mathrm{GmbH}$ and Co., KG, Ettlingen, Germany) is one of the preferred material. Mollosil is a kind of soft lining material, which can be applied directly in the mouth in a short time and commonly used in the clinic, so Mollosil was chosed in this study.

In line with the previous studies ${ }^{17,29,30}$ tensile, shear and peel tests are widely accepted methods for evaluating the bond strength of soft lining materials to denture base. Tensile test was used in this study.

Soft lining materials are used as long term denture liners for the management atrophied mucosa or traumatic ulceration and for obturators after maxillofacial surgery. ${ }^{31}$ One of the major serious problems with soft denture liners is unseccess bonding between the soft liner material and denture base. ${ }^{32-36}$ The soft lining material can be a hard structure and

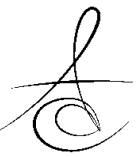


ineffective din the mouth. ${ }^{37}$ For this reason the soft lining materials must be strong bond strength between denture base materials. This bonding can be achieved by different surface treatments.

Jacobsen et al. ${ }^{15}$ reported that surface treatment with a $\mathrm{CO}_{2}$ laser was ineffective in reducing adhesive failure of soft-lined prostheses in a clinical situation. In their study, Akın et al. ${ }^{38}$ investigated the effect of different surface treatments of PMMA acrylic denture base resin on the tensile bond strength of a silicone- based soft denture liner. Gundogdu et al. ${ }^{39}$ showed that pretreatment with a laser, acid + laser, or abrasion+ laser did not increase tensile bond strength. Abrasion pretreatment weakened the tensile bond strength between soft lining materials and acrylic dentures.

In this study, the specimens, which had been applied mechanical retention with a bur, have shown more bonding strength. The probable cause of this, the soft lining materials could be had more bonding area because of the surface roughness.

However, the polyamide denture has a flexible structure, can cause trauma at some patients, pain the extremely resorbed crest and the soft lining materials should be used in these cases. There are not enough investigation about the bond strength of polyamide denture and soft lining materials. Korkmaz et al. ${ }^{40}$ have found that, air abrasion of polyamide resins should be avoided not to impair their peel bond strengths to silicon-based soft denture liners.

\section{CONCLUSION}

With regard to the results, it was determined that, surface treatments not effected to the bond strength between polyamide denture and soft lining material. The grinding with a bur a bit increased the bond strength.

\section{ACKNOWLEDGEMENTS}

Presented as a poster at $38^{\text {th }}$ Annual Conference of the European Prosthodontic Association $\& 21^{\text {st }}$ Scientific Congress of the Turkish Prosthodontic and Implantology Association (EPA 2014) in Istanbul, Turkey, September 2014.

\section{REFERENCES}

1. Marei MK. Reinforcement of denture base resin with glasscfiller. J Prosthodont 1999;8:18-26.
2. Stipho HD. Effect of glass fiber reinforcernent on some mechanicalcproperties of autopolymerizing polymethyl methacrylate.c] Prosthet Dent 1998; 79: 580-4.

3. Jagger $D$, Harrison $A$, Jagger $R$, Milward $P$. The effect of thecaddition of poly (methyl methacrylate) fibres on some propertiescof high strength heat-cured acrylic resin denture basecmaterial. J Oral Rehabil 2003;30:231-5.

4. Jagger DC, Harrison A, Jandt KD. The reinforcement ofcdentures. J Oral Rehabil 1999;26:185-94.

5. Dogan OM, Bolayır G, Keskin S, Doğan A, Bek B, Boztuğ $A$. The effect of esthetic fibers on impact resistance of a conventional heat-cured denture base resin. Dent Mater J 2007; 26:232-9.

6. Nakamura $M$, Takahashi $H$, Hayakawa I. Reinforcement of denture base resin with short-rod glass fiber. Dent Mater J 2007;26:733-8.

7. Uçar Y, Akova T, Aysan I. Mechanical properties of polyamide versus different PMMA denture base materials. J Prosthodont 2012;21:173-6.

8. Phoenix RD, Mansueto MA, Ackerman NA, Jones RE Evaluation of mechanical and thermal properties of commonly used denture base resins. J Prosthodont 2004;13:17- 27.

9. Yunus N, Rashid AA, Azmi LL, Abu-Hassan MI. Some flexural properties of a nylon denture base polymer. J Oral Rehabil 2005;32:65-71.

10. Bolayır G, Turgut $M$, Hubbezoğluİ, Doğan OM, Keskin S, Doğan A, Bek B. Evaluation of laser treatment on relinebase composites. J Adhesion 2007;83:117-27.

11. Sertgöz A, Kulak Y, Gedik H, Taskonak B. The effect of thermocycling on peel strength of six soft lining materials. J Oral Rehabil 2002;29:583-7.

12. Hatamleh MM, Watts DC. Bonding of maxillofacial silicone elastomers to an acrylic substrate. Dent Mater 2010;26:387- 95.

13. Sertgöz A, Kulak Y, Gedik H, Taskonak B. The effect of thermocycling on peel strength of six soft lining materials. J Oral Rehabil 2002;29:583-7

14. Usumez A, Inan O, Aykent F. Bond strength of a silicone lining material to alumina-abraded and lased denture resin. J Biomed Mater Res B Appl Biomater 2004;71:196-200.

15. Jacobsen NL, Mitchell DL, Johnson DL, Holt RA. Lased and sandblasted denture base surface preparations affecting resilient liner bonding. J Prosthet Dent 1997;78:153-8 
16. Uzun G, Keyf F. Aşırı rezorbe krete sahip geriatrik bir hastaya yumuşak astar maddesi uygulaması. Atatürk Univ. Diş Hek. Fak. Derg 2012;22:191-196

17. Kawano F, Ohguri T, Koran III A, Matsumoto N, Ichikawa $T$. Influence of lining design of three processed soft denture liners on cushioning effect. J Oral Rehabil 1999;26:962-8

18. Pinto JR, Mesquita MF, Henriques $G E$, de ArrudaNóbilo MA. Effect of thermocycling on bond strength and elasticity of 4 long-term soft denture liners. J Prosthet Dent 2002;88: 516-21

19. Aydin AK, Terzioğlu $H$, Akinay $A E$, Ulubayram $K$, Hasirci $\mathrm{N}$. Bond strength and failure analysis of lining materials to denture resin. Dent Mater 1999;15:211-8.

20. McCabe JF, Carrick TE, Kamohara H. Adhesive bond strength and compliance for denture soft lining materials. Biomaterials 2002;23:1347-52

21. Sarac D, Sarac YS, Basoglu T, Yapici O, Yuzbasioglu E. The evaluation of microleakage and bond strength of a siliconebased resilient liner following denture base surface pretreatment. ] Prosthet Dent 2006;95:143-51.

22. Pisani $\mathrm{MX}$, Silva-Lovato $\mathrm{CH}$, Malheiros-Segundo Ade L, Macedo AP, Paranhos HF. Bond strength and degree of infiltration between acrylic resin denture liner after immersion in effervescent denture cleanser. J Prosthodont 2009;18:123-9.

23. Al-Athel M, Jagger R, Jagger D. Effect of ageing on the bond strength of a permanent denture soft lining material. J Oral Rehabil 2002;29:992-6.

24. Tanimoto $Y$, Saeki $H$, Kimoto $S$, Nishiwaki T, Nishiyama N. Evaluation of adhesive properties of three resilient denture liners by the modified peel test method. Acta Biomater 2009; 5:764-9.

25. Waters MG, Jagger RG. Mechanical properties of an experimental denture soft lining material. J Dent 1999;27:197-202.

26. Tugut $F$, Akin $H$, Mutaf $B$, Akin GE, Ozdemir AK. Strength of the bond between a silicone lining material and denture resin after Er:YAG laser treatments with different pulse durations and levels of energy. Lasers Med Sci 2012;27:281-5.

27. Baysan A, Parker S, Wright PS. Adhesion and tear energy of a long-term soft lining material activated by rapid microwave energy. J Prosthet Dent 1998;79:182-7.

28. Braden M, Wright PS, Parker S. Soft lining materials-a review. Eur J Prosthodont Restor Dent 1995;3:163-74.
29. Kulak-Ozkan Y, Sertgoz A, Gedik H. Effect of thermocycling on tensile bond strength of six silicone-based, resilient denture liners. J Prosthet Dent. 2003;89:303-10.

30- Pinto JR, Mesquita MF, Nóbilo MA, Henriques GE. Evaluation of varying amounts of thermal cycling on bond strength and permanent deformation of two resilient denture liners. J Prosthet Dent. 2004;92:288-93.

31. Craig RG. Restorative dental materials, 7th ed, CV Mosby Co, St. Louis, 1986, pp.496-498.

32. Sauve JL. Clinical evaluation of silastic 390 as a lining material for dentures. J Prosthet Dent 1966; 16: 650- 60.

33. Kawano F, Dootz ER, Koran A, Craig RG. Sorption and solubility of 12 soft denture liners. J Prosthet Dent 1994; 72: 393-398.

34. Waters MG, Jagger RG, Winter RW. Water absorption of (RTV) silicone denture soft lining material. J Dent 1996; 24: 105-108.

35. Emmer TJ Jr, Emer TJ Sr, Vaidynathan J, Vaidynathan TK. Bond strength of permanent soft denture liners bonded to the denture base. J Prosthet Dent 1995; 74: 595-601.

36. Kawano F, Dootz ER, Koran A. Comparison of bond strength of six soft denture liners to denture base resin. J Prosthet Dent 1992; 68: 368-371.

37. Wilson HJ, Tomlin HR. Soft lining materials: some relevant properties and their determination. J Prosthet Dent 1969; 21: 244-250.

38. Akin H, Tugut $F$, Mutaf B, Akin G, Ozdemir AK. Effect of different surface treatments on tensile bond strength of silicone-based soft denture liner. Lasers Med Sci 2011;26:783-8.

39. Gundogdu M, Yesil Duymus Z, Alkurt M. Effect of surface treatments on the bond strength of soft denture lining materials to an acrylic resin denture base J Prosthet Dent. 2014 Oct;112(4):964-71

40. Korkmaz FM1, Bagis B, Ozcan M, Durkan R, Turgut $S$, Ates SM. Peel strength of denture liner to PMMA and polyamide: laser versus air-abrasion. J Adv Prosthodont. 2013 Aug;5(3):287-95

\section{Yazışma Adresi}

Arş. Gör. Dr. Alper Özdoğan, Atatürk Üniversitesi, Diş Hekimliği Fakültesi Protetik Diş Tedavisi AD. 25240/Erzurum-TÜRKİYE TIf: 04422360944

Fax: 04422360945

E mail: alprozdgn@gmail.com 